\title{
The European Fiscal Compact: A Counterfactual Assessment
}

\author{
Jérôme Creel \\ OFCE \& ESCP Europe \\ Paul Hubert \\ OFCE \\ Francesco Saraceno \\ $O F C E$
}

\begin{abstract}
Faced with the global financial crisis and an increasingly worrisome sovereign-debt crisis, the Eurozone countries are rethinking their fiscal governance. This paper discusses the different reforms and subsequent fiscal rules which have emerged since 2011. It assesses the impact of fiscal rules on the output gap and inflation rate of three representative countries of the Eurozone. By means of a counterfactual, the rules based upon their macroeconomic outcomes are ranked. The new debt reduction rule would certainly lead to lower debt levels, hence to larger fiscal margins for maneuver in the future but, in steep contrast with the golden rule of public finance, it would be very costly to implement as the requirement to enforce a substantial consolidation in the short run would be considerably higher than that of a golden rule and would worsen the output gap and inflation rate. The cap on the cyclically adjusted deficit also leads to unfavorable outcomes whereas the Maastricht status quo, limiting overall public deficit, would be a "second best" behind the golden rule of public finance.
\end{abstract}

JEL Classifications: C54, E62, H68

Key Words: EMU, Fiscal compact, Stability and Growth Pact, Fiscal rules, Counterfactual

\footnotetext{
* Corresponding Author: J. Creel; OFCE \& ESCP Europe, 69, quai d'Orsay, 75340 Paris cedex 07, France, Tel: +33 144185456 , Email: jerome.creel@sciences-po.fr;

Co-Author: P. Hubert; OFCE, 69, quai d'Orsay, 75340 Paris cedex 07, France, Tel: +33 1441854 27, Email: paul.hubert@sciences-po.fr; F. Saraceno; OFCE, 69, quai d'Orsay, 75340 Paris cedex 07, France, Tel: +33 1441854 93, Email: francesco.saraceno@ sciences-po.fr.
} 


\section{Introduction}

The sovereign debt crisis has challenged some Euro area countries since the last quarter of 2009. In 2011 and 2012, risks of default and contagion effects to the rest of the area arose and paved the way for European governance reforms. The climax of reform was reached on March 2, 2012 when 25 of the 27 EU countries (the UK and the Czech Republic stepped down) adopted the Treaty on Stability, Coordination, and Governance in the Economic and Monetary Union. This so-called "Fiscal Compact" complemented the provisions of the "revised Stability and Growth Pact" of November 16, 2011 with a new fiscal rule: the balanced structural budget rule.

The focus by EU authorities on further limiting deficits and debts, in a context of slow growth, confirms a long-lasting trend in EU governance that public deficit and debt are not to be managed with the objective of smoothing the cycle and reducing unemployment, but are rather to be considered an objective. ${ }^{1}$ The European-renewed emphasis on transforming a policy instrument into a policy objective is rather paradoxical. First, the misbehaviors that emerged in 2009, notably in the management and in the reporting of public finances by the Greek authorities, triggered a discussion that went well beyond the need for increased and more efficient monitoring of public finances. Markets and policy-makers have brought into the spotlight countries like Spain and Ireland, where the surge in deficit and debt was not linked to public sector wrongdoings, but rather to the need to correct strong imbalances in the private sector. Second, the global crisis that started in 2007 saw in a first phase monetary policy interventions and then a liquidity trap situation that called for traditional textbook fiscal stimulus packages in most developed and emerging economies. It has been almost unanimously acknowledged that proactive monetary and fiscal policies dampened the global crisis. Hence, policy instruments and policy objectives were clearly separated, and instruments were effective at reaching the objective.

This paper aims to contribute to the debate about EU governance, shifting back the attention to what should be the objective of policy action, growth, and output gap. An assessment of the impact of different fiscal rules, including an investment rule consistent with the golden rule of public finance, on the output gap of three economies taken as representatives of the Eurozone is thus given through a large and relatively low-debt economy (France), a small high-debt one (Belgium), and a large high-debt one (Italy). In focusing on the input that came from the European institutions, the recent EU governance reforms are analyzed, hence the balanced budget requirement and the debt reduction scenario by one-twentieth of the gap with the 60 percent

\footnotetext{
'Since the devil is in the details, one counterargument to this paper's line of reasoning can state that the new balanced budget rule is expressed as a cyclically adjusted deficit of $0.5 \%$ of GDP. One may argue that this leaves sufficient margins for maneuver to smooth the cycle. This paper has a different view. First, in a survey about EU automatic stabilizers, Creel and Saraceno (2010) clearly showed that automatic stabilizers have been weakening since the 1990s and that their effectiveness has also decreased. Second, the global crisis had strong negative consequences on EU potential output (see, e.g., DG EcFin, 2009; van Ark, 2010; DG Ec Fin, 2011), and the use of fiscal instruments beyond automatic stabilizers can still be required.
} 
limit per year (Article 4 of the "Fiscal Compact"). Four fiscal rules, are ranked based upon their macroeconomic outcomes.

The paper is structured as follows: A critical account of the SGP and reforms is given in Section 2. A counterfactual experiment is performed in Section 3 in the line of Eichengreen and Wyplosz (1998) to give a quantitative assessment of the output and inflation performance for different fiscal rules. A conclusion is provided in Section 4.

\section{A Critical Appraisal of the New EU Governance Reforms}

The global crisis and the subsequent events make it clear that the SGP needed reforms anew. Past evaluations already pointed to the weaknesses of the EU fiscal framework (De Grauwe, 2006; Wyplosz, 2006); for instance, the numerical rules had no economic rationale as they drew on the European average public debt ratio and economic growth rate of the early 1990s, and the target of medium term equilibrium for public balances made little economic sense as it led to a zero public debt level. During the global crisis, the SGP limited the scope for discretionary fiscal policy at the very moment it was needed; the SGP imposed premature exit strategies to abide by the numerical limits even though recovery was not completed. Moreover, the SGP also failed to be a preventive arm against fiscal profligacy or fiscal laxity: Greece had had public deficits above the authorized limit at least since 1999 when, according to the OECD, the public deficit was still above the limit at $3.1 \%$ of GDP. Though the responsibility of the Greek authorities in this situation could not be dismissed, the EU fiscal framework was ineffective in enforcing the commonly approved fiscal rules.

It is puzzling that almost none of these drawbacks have been dealt with by the outstanding list of reforms which were adopted by the EU in 2011 and 2012, with the exception of the enhancement in the EU's control over national public finances.

The European Commission's public communication ${ }^{2}$ confirms the impetus for reforms that initiated in 2011. These reforms were adopted by the Council of the EU and the European Parliament between March and November 2011, prior to the adoption of the Fiscal Compact.

After the adoption of the Euro+ Pact on March 11, 2011 which was intended to enhance policy coordination for competitiveness and convergence, the European Council of March 24 and 25 in 2011 paved the way for strengthening economic governance with enhanced fiscal discipline through improved surveillance, better enforcement of the SGP provisions, and commitment to translate EU fiscal rules into national legislation. Besides public finances, surveillance was extended to macroeconomic imbalances with the introduction of a scoreboard to help

${ }^{2}$ http://ec.europa.eu/economy_finance/economic_governance/index_en.htm. 
detect improvements or deterioration in competitiveness and convergence. ${ }^{3}$

In the following subsections, an appraisal of the different arguments that led to these reforms is given.

\section{A. Prudent Fiscal Policy}

The principle of "prudent fiscal policy" introduces a new constraint on fiscal policy: the growth rate of government expenditure should normally not exceed a reference medium-term rate of potential GDP growth, with increases in excess of that norm being matched by discretionary increases in government revenues and discretionary revenue reductions being compensated by reductions in expenditure.

Estimating "potential GDP growth" is not a consensual task. There are obviously many ways to assess potential output, some based exclusively on past data (but these assessments by definition have no forecasting power) and some based on theoretical production functions that might well be theoretical only. Moreover, the potential output can be made instrumental to the fiscal stance as under(over)-estimating the potential output leads to over(under)-estimating the fiscal stance. Thus, the implementation of such a rule will need a serious discussion on who takes the responsibility and the accountability for estimating the reference rate of potential growth. The responsibility of the European Commission in this respect, even if it has been transparent on the method it is using, has to be shared with other institutions, national governments and/or the European parliament; otherwise, there will be scope for ex post disagreements on the optimal fiscal stance. Certainly the Commission cannot be judge and jury.

Abiding by the "prudent rule" will certainly make it ever more difficult to implement policy support to GDP growth through an increase in public spending. If the output loss from the financial crisis is assumed to be permanent, a mild potential growth will require a mild progression in public spending so that inflation expectations remain low, except if some expenditures are cut in order to boost, say, public investment. Hence, the prudent rule and the underestimation of potential output reduce the scope for short-term expansionary fiscal policy and internalize the idea that discretionary policies (whether a tax or a spending one) can be detrimental to economic growth. This reasoning is rather controversial. Fiscal multipliers in the empirical literature point, with only a few exceptions, to a positive impact of fiscal policy on GDP, not only in the USA, but also in Germany, France, Italy, Spain, or the entire Eurozone (see among others Creel et al., 2009; Hall, 2009; Mountford and Uhlig, 2009; Leigh et al., 2010; Romer and Romer, 2010; Coenen et al., 2012). Within this literature, at least two recent contributions

\footnotetext{
Knedlik and von Schweinitz (2011) assess the signaling power of the scoreboard variables for the occurrence of debt crises.

${ }^{4}$ Regulation (EU) n 1175/2011 of the European Parliament and of the Council of 16 November 2011 amending Council Regulation (EC) No. 1466/97 on the strengthening of the surveillance of budgetary positions and the surveillance and coordination of economic policies.
} 
also conclude that the more negative the output gap is, the more effective fiscal policy will be (Creel et al., 2011; DeLong and Summers, 2012).

\section{B. The Fiscal Compact}

With the Fiscal Compact, EU governments and the European Commission have decided to adopt fiscal rules which limit the fiscal room for maneuver beyond the reformed Stability and Growth Pact of 2005. The Fiscal Compact imposes two new rules: first, the objective of balanced budget is respected if the structural (or cyclically-adjusted) deficit is below $0.5 \%$ of GDP; second, countries whose public debt exceeds $60 \%$ of GDP reduce their debt "at an average rate of one-twentieth per year as a benchmark."

The balanced structural budget rule introduces two novelties in comparison with the former SGP: first, the limit at $0.5 \%$ of GDP, and, second and consequently, the speed of adjustment towards this limit losing its country-specificity. The latter fact may lead to unfairness in the assessment of the adequacy of the fiscal stance by the European Commission in two countries with similar structural deficits but different levels of initial debt, for instance. Imagine Countries $\mathrm{A}$ and $\mathrm{B}$ having a structural deficit of $1 \%$ of GDP each and their respective output gap being zero (they have no cyclical deficit). Imagine that public debt in Country A is $100 \%$ of GDP, whereas it is $50 \%$ in Country B. Progress towards the balanced structural budget rule requires a tougher discretionary effort in Country A than in country B, though their overall situation in terms of flows is similar. This extra burden compounds the larger interest payments of Country A that, as a consequence, is penalized twice. The fact that "respect of the medium-term objective shall be evaluated on the basis of an overall assessment with the structural balance as a reference, including an analysis of expenditure net of discretionary revenue measures" (Article 3 ), it is not clear and comprehensive enough to make sure that unequal treatment as regards the new structural rule can be disregarded.

As for the new debt rule, and though it is contingent on exceptional circumstances like a period of severe economic downturn, at least two drawbacks remain of the former SGP framework. First, and like the balanced structural budget rule, it is not "country-specific." Although two countries may differ, e.g., in terms of private debt, the target of public indebtedness is similar for both. Second, it is unlikely that a slower pace of economic growth can be labeled "severe downturn." Nevertheless, slower growth can have a substantial incidence on the required surplus for decreasing debt. Drawing on the law of motion for public debt, and under the assumption of an initial debt at $100 \%$ of GDP and a real interest rate at $2 \%$ per year, the public surplus which is required to fulfill the debt reduction increases from $2 \%$ to $3 \%$ of GDP if the growth rate slows from $2 \%$ to $1 \%$.

Beyond these drawbacks, the vagueness of the debt reduction rule leaves excessive room for interpretation. As a matter of fact, Article 4 of the Fiscal Compact states, "When the ratio 
of the Contracting Party's general government debt to GDP exceeds the $60 \%$ reference value (...), that Contracting Party shall reduce it at an average rate of one-twentieth per year as a benchmark." Is it the difference between the effective ratio of debt to GDP and the targeted ratio which has to decrease by $5 \%$ per year or is it the effective ratio itself? In the first case, and still drawing on a country with initial debt at $100 \%$, debt must be reduced by $2 \%$ of GDP each year, whereas in the second case, it must be decreased by $5 \%$ of GDP each year. In the following text, the first interpretation which is closer to a former proposition by the European Commission, presented before the adoption of the "six-pack", will be used.

\section{The "European Semester"}

In June 2010 the Commission proposed the introduction of a "European semester," which started being implemented on January 1, 2011 after it was agreed upon by the European Council on September 7, 2010.

The European Semester can be defined as a succession of round trips between the Commission, the European Council (and the Council of the European Union), and the European Parliament about the Annual Growth Surveys (AGS). AGS are published at the end of each year and they report economic forecasts and policy recommendations for EU Member States for the next year. During the subsequent $1^{\text {st }}$ semester, the European Parliament and the Council debate the AGS before the Council and the Commission address policy guidelines to the Member States at the end of the semester. These guidelines have to be implemented and incorporated in planned fiscal policies and structural reforms. Hence, the important novelty of the procedure is that the Commission, the European Parliament, and the European Council express an opinion on future planned policies and reforms before the vote by national parliaments during the second semester of each year. Therefore, national parliaments are supposed to be (more or less) constrained by decisions taken at the EU level.

The "European Semester" raises two comments. First, a procedure of debate and guidance is useful to implement a coordinated economic strategy. In a Nash-bargaining theoretical framework, cooperative policies are always Pareto-improving (see Nash, 1950, 1953 and Rubinstein et al., 1992). Hence, it can be argued that the "semester" will enhance coordination at the European level. But it must be acknowledged that theory and practice may often differ. In the present context, the analytical theoretical framework on which forecasts and policy recommendations are based upon requires a thorough and transparent assessment. It is important that no theoretical bias interferes with the quality of the AGS. For example, there must be no asymmetry between, on the one hand, increased pressures for more austerity in fiscal policies and further structural reforms and, on the other hand, increased pressure for higher fiscal spending and support for the welfare state when it can be judged necessary. The first kind of recommendation has been frequent during the European sovereign debt crisis, though the latter kind of 
pressure could have well dampened the costs of fiscal retrenchment.

\section{Macroeconomic Imbalances}

The "six-pack" adopted on November 16, 2011 introduced two Regulations (1174 2011 and 1176 2011) dedicated to the prevention, monitoring, and correction of excessive macroeconomic imbalances. The main innovations are, first, the inclusion of a scoreboard of macro indicators with thresholds, and second, the creation of an excessive imbalance procedure (EIP).

The scoreboard reflects indicators of either internal or external disequilibrium. They are used to detect early imbalances that may be dysfunctional for a Member State economy, for the Eurozone, or for the entire EU. Internal disequilibria are scrutinized through data of public and private indebtedness, stock and real estate prices, credit flows, and unemployment. External disequilibria are scrutinized through current account balances, net external positions, real effective exchange rates, market shares, and nominal unit labor costs.

After an in-depth review, the Council can send recommendations to a country experiencing excessive macro imbalances. The Council imposes an interest-bearing deposit to the country under the excessive imbalance procedure. If the country does not take the recommended corrective actions, the deposit is transformed into a fine, amounting to $0.1 \%$ of the Member State's GDP in the previous year.

The main drawback with the scoreboard is its asymmetry: surpluses and deficits are not weighed equally, and the cost of adjustment rests almost exclusively on debtor countries. This may sound strange in a deeply integrated area where the current account deficits of some countries are the counterparts of the current account surpluses of some other countries. Another drawback relates to the comparative nature of some indicators within the scoreboard, e.g. competitiveness. By definition, competitiveness cannot be improved for all countries alike. In a deeply integrated area like the Eurozone or the EU, it means that weakly competitive countries can only improve their situation at the expense of competitive ones.

A first example of the asymmetry issue with the scoreboard is the current account balance's threshold. It has been set between a surplus of $6 \%$ of GDP and a deficit of $4 \%$ of GDP, although no rationale justifies such figures and asymmetry. Other indicators of the scoreboard are even more asymmetric. This is notably the case for the change in export market shares, which only has a negative threshold (-6\%) but no upper limit although the improvement in market shares requires a decrease in other Eurozone countries. The same reasoning applies to nominal unit labor costs (with thresholds at $+9 \%$ and $+12 \%$ ) as countries pursuing excessive reductions of labor costs are not penalized for depressing their internal demand. Hence, there is a potential bias in signaling only a certain type of imbalance. It will indeed skip the fact that a loss in the export market shares of a Eurozone country may have as a counterpart an improvement of export market shares in another Eurozone country. Therefore, a risk exists, confirmed by the 
recent Eurozone crisis developments, that recommendations will be geared toward deficit countries urging them to adjust wage costs or to implement restrictive policies. Surplus countries that have run non-cooperative competitive disinflation policies are not signaled, and even less sanctioned. By only signaling a loss in competitiveness, the scoreboard will actually miss to detect coordination issues among Eurozone countries.

The result of a biased assessment of macro imbalances can lead the Eurozone to adopt a global deflationary policy. A similar remark holds for the monitoring of internal imbalances. By considering only the increases in private sector credit flows, the scoreboard exclusively signals Member States in a situation of overheating, whereas weaknesses of internal demand may also be a source of disequilibrium. Slowing the growth of credit flows may, for example, signal a situation of credit crunch or a sustained weakness in internal demand. Thus, it seems it would be useful to add a lower limit for the credit flows to the private sector since symmetry in the monitoring of macro imbalances would be enhanced.

\section{E. National Fiscal Frameworks}

According to the preamble of the treaty on stability, coordination, and governance in the EMU, the 25 ratifying Member States must comply with the obligation to transpose the "balanced budget rule" into their national legal systems through "binding, permanent, and preferably constitutional provisions."

This decision affects the independence of Member States and is a step towards the de-politicization of fiscal policies. Fiscal choices, whose nature is intrinsically political, are increasingly in the hands of non-elected bodies. Moreover, this decision increases the rigidity of rules that already in their present form tend to introduce a restrictive bias. It also gives a higher priority to public finance balance than to macroeconomic balance, once again giving to instruments (fiscal policy) the status of final objectives.

After the adoption of a treaty, a directive and, at least, five regulations, the debate continues on the adequacy of fiscal rules that all seem to share the feature of increasing the restrictive bias of the former rules. Restrictiveness is also a common feature of the two-pack proposals of late 2011, which have been discussed throughout the first semester of 2012. The two regulations under discussion would reinforce the control of Member States that may face financial instability, although they may not have public finance disequilibrium. They would also establish common procedures to assess fiscal domestic planned policies and would reinforce the correction of excessive deficits. The next section will try to quantify to which extent the different EU fiscal rules can be detrimental to GDP and/or inflation. 


\section{Assessing the Impact of Four Fiscal Rules}

The medium-to-long term performance of European economies will crucially depend on the macroeconomic governance tools put in place by the EU. As the previous section made clear, three fiscal rules have been on the floor, adopted or discussed by EU governments, since 2011: (a) a status quo where public deficits must be maintained below the $3 \%$ of GDP limit (with the objective of a balanced deficit over the cycle); (b) an unconditional diminishing rate of public debt towards the $60 \%$ of GDP reference value (the distance with respect to this reference value has to decline in the order of one-twentieth per year); (c) a balanced structural budget where the (cyclically adjusted) structural deficit must not exceed $0.5 \%$ of GDP. Beyond these three rules, an alternative reform proposal that was proposed by the Italian Prime Minister in 2012 will be tested: a "golden rule of public finance" is a balanced public current budget where public investment is financed with debt issuance. These four rules differ on the criteria and on the type of constraints they impose on countries.

We assess the potential impact of these rules on growth and inflation. In a Eurozone where spillovers from one country to the other are so important and with a contagion effect due to budget deficits or a trade effect caused by the strong integration between members inevitable, a multi-country assessment is required.

\section{A. The Method}

A comparison between various fiscal rules within a simple and extended simulation exercise has thus been performed in the vein of Eichengreen and Wyplosz (1998) and MonperrusVeroni and Saraceno (2005). These exercises start from a simple parsimonious reduced-form VAR model that has its theoretical basis in a new Keynesian aggregate demand/Phillips curve whereby the dependent variables are the output gap and inflation, while domestic public deficits and debts are the exogenous explanatory variables. The estimation results are then the basis for a counterfactual assessment of the effect of alternative budgetary rules. Such an exercise has shortcomings acknowledged by Eichengreen and Wyploz(1998). The main one is that it represents a typical Lucas' Critique victim: had the rules been applied in the past, agents would have embedded their consequences in their behavior which would have then been different from the current one. Actual data hence have a limited explanatory power when trying to quantify the effects of alternative policies. The paper by Eichengreen and Wyplosz nevertheless retained a remarkable interest because it gave a measure of the magnitude of costs and benefits of the Pact; furthermore, in this paper's extension, it has the advantage of allowing a meaningful and consistent comparison of different institutional arrangements.

Eichengreen and Wyplosz followed a three-step procedure: (1) they estimated the reduced 
form of a two-equation VAR with output gap and inflation changes as endogenous variables. Among the exogenous variables, they introduced the fiscal impulse (that they defined as the change in structural deficit) and a dummy variable to capture recessions. (2) They used the estimated coefficients and an artificial series for the fiscal impulse (derived by capping total deficit at $3 \%$ for each period in which it surpassed the threshold) to build the simulated series for output gap and inflation. (3) The simulated output gap series were finally compared to the actual one to compute the difference in output.

A similar procedure to rank different fiscal rules has been used. The first difference with the previous authors is that this paper made an out-of-sample estimation, projecting the series of output gap, inflation, and debt starting from 2010 onwards (for 2 decades). The second difference is that a loss function-a metric-to rank the performance of the various rules was used.

The methodology to assess the effect of the different fiscal rules in a multicountry framework is extended. The paper aims to assess whether the size of countries, expressed in terms of their GDP, or the size of initial debts create different spillovers on their partner countries. The choice of countries is thus dictated by their close trade integration and their differentiated size and initial debts. The VAR includes three countries: Belgium, France and Italy, where France stands for a large country with relatively low public debt, Italy for a large country with relatively high debt and Belgium for a small country with relatively high debt. Beyond Germany, Belgium and Italy are France's main trade partners within the Eurozone.

The choice of these three countries has also been dictated by the availability of data. Eichengreen and Wyplosz' procedure requires a long time sample for the VAR estimated coefficients to have as much statistical significance as possible. For this reason, Germany was left out of the exercise (the German reunification makes it impossible to start the dataset before 1991 for that country or at least to do so without imposing arbitrary manipulation of the data) hence the two "large" countries were naturally France and Italy. This has also suggested Belgium as a natural candidate for the small country in view of its strong trade links with France.

Differently from Eichengreen and Wyplosz, this paper's VAR also included the change in public debt (expressed in percent of GDP) and country dummies meant to capture episodes of extreme changes in the output gap. Data come from the OECD annual database and the sample is 1972 2008. Appendix A provides more details on the estimation method and results.

\section{B. Single Country Assessments}

This section begins with single country VAR estimation results for Belgium, France and Italy (Table 1). These results can be used to give a first assessment of the impact of fiscal policies on GDP (in the short run, at constant potential output) and on the output gap (in the long run, when the output gap has stabilized). They also legitimize the use of the parsimonious VAR that fits the literature on the fiscal multiplier effect (see, e.g., Ilzetzki et al., 2010). 
On the one hand, Table 1 shows the negative impact of a fiscal contraction in the short and the long run; for instance, in France, a permanent reduction in the fiscal deficit by $1 \%$ of GDP reduces GDP by $0.3 \%$ in the short run and by $0.8 \%$ in the long run. For the three countries, a reduction in the fiscal deficit by $1 \%$ of GDP reduces GDP by $0.2 \%$ in the short run and by $0.5 \%$ in the long run on average. For these countries, the non Keynesian crowding-in effects (if any) are more than compensated by the standard textbook contractionary effect of fiscal consolidations. This paper's results are thus in line with what was found in the previous literature (notably Eichengreen and Wyplosz, 1998 and Monperrus-Veroni and Saraceno, 2005).

This paper's estimations show on the other hand that a permanent reduction in the public debt-to-GDP ratio increases GDP. Hence, if the fiscal contraction were entirely used to repay public debt (it could well be that a fiscal restriction at time $t$ was used to increase expenditures and/or to decrease taxes at time $t+1$ ), the net effect of a fiscal contraction on GDP would be dampened. However, except in Italy where it is nil, the net effect remains negative and a fiscal contraction produces a negative effect on GDP.

Table 1. Impact of Domestic Fiscal Policy on Domestic GDP (without cross effects)

\begin{tabular}{|l|c|c|c|c|c|c|}
\hline & \multicolumn{2}{|c|}{ Belgium } & \multicolumn{2}{c|}{ France } & \multicolumn{2}{c|}{ Italy } \\
\hline & $\begin{array}{c}\text { Short } \\
\text { run }\end{array}$ & $\begin{array}{c}\text { Long } \\
\text { run }\end{array}$ & $\begin{array}{c}\text { Short } \\
\text { run }\end{array}$ & $\begin{array}{c}\text { Long } \\
\text { run }\end{array}$ & $\begin{array}{c}\text { Short } \\
\text { run }\end{array}$ & $\begin{array}{c}\text { Long } \\
\text { run }\end{array}$ \\
\hline Impact on GDP (in \%)... & & & & & & \\
\hline $\begin{array}{l}\ldots \text { of a permanent fiscal contraction of } \\
1 \% \text { of GDP }\end{array}$ & -0.25 & -0.50 & -0.28 & -0.80 & -0.12 & -0.30 \\
\hline $\begin{array}{l}\ldots \text { of a permanent debt reduction of } \\
1 \% \text { of GDP }\end{array}$ & +0.10 & +0.20 & +0.18 & +0.50 & +0.11 & +0.30 \\
\hline Net effect & -0.15 & -0.30 & -0.10 & -0.30 & +0.00 & +0.00 \\
\hline
\end{tabular}

(Source) OECD, author's computations

\section{Quantifying Cross Country Spillovers}

The single country framework is then extended to analyze pairwise (France-Italy and France-Belgium) spillovers between two large countries and between a large and a small country. Table 2 reports the net effect of a domestic fiscal contraction which would be entirely used to repay debt. Table 2 shows that even with cross effects, the effect of the permanent fiscal contraction is comprised between -0.3 and zero in the short run, and between -0.7 and zero in the long run, depending on the country. In the short run, the maximum impact (in absolute terms) of a fiscal contraction (that is not used to repay debt) is 0.3 in Belgium, 0.4 in France, and 0.05 in Italy. In the long run, the maximum impact (in absolute terms) of a fiscal contraction is 0.6 
in Belgium, 0.9 in France, and 0.1 in Italy. The "one-size-fits-all" dimension of European fiscal rules appears at odds with these outcomes, since the latter show the strong diversity in terms of fiscal policy impact for three European countries with close financial and trade relationships.

Table 2. Impact of Domestic Fiscal Policy on Domestic GDP (with cross effects)

\begin{tabular}{|l|c|c|c|c|c|c|}
\hline & \multicolumn{2}{|c|}{ Belgium } & \multicolumn{2}{c|}{ France } & \multicolumn{2}{c|}{ Italy } \\
\hline & $\begin{array}{c}\text { Short } \\
\text { run }\end{array}$ & $\begin{array}{c}\text { Long } \\
\text { run }\end{array}$ & $\begin{array}{c}\text { Short } \\
\text { run }\end{array}$ & $\begin{array}{c}\text { Long } \\
\text { run }\end{array}$ & $\begin{array}{c}\text { Short } \\
\text { run }\end{array}$ & $\begin{array}{c}\text { Long } \\
\text { run }\end{array}$ \\
\hline Impact on GDP (in \%)... & & & & & & \\
\hline $\begin{array}{l}\ldots \text { of a permanent fiscal contraction of } \\
1 \% \text { of GDP }\end{array}$ & -0.31 & -0.62 & -0.37 & -0.93 & -0.05 & -0.12 \\
\hline $\begin{array}{l}\ldots \text { of a permanent debt reduction of } \\
1 \% \text { of GDP }\end{array}$ & +0.10 & +0.2 & +0.08 & +0.20 & +0.07 & +0.15 \\
\hline Net effect & -0.21 & -0.42 & -0.30 & -0.73 & +0.02 & +0.03 \\
\hline
\end{tabular}

(Source) OECD, author's computations

Finally, an assessment of a coordinated fiscal policy implemented by two European countries is given: Belgium and France, and France and Italy. A standard multiplier analysis would lead one to expect the effects of fiscal policies to be enhanced when both policies are coordinated as the leakage from imports is compensated by the effect on exports. Table 3 confirms this guess and shows that a coordinated permanent fiscal contraction in Belgium and France increases significantly the costs in terms of GDP. In the short run, the maximum impact in absolute terms of a fiscal contraction that is not used to repay debt is 0.6 in Belgium and in France. In the long run, the maximum impact in absolute terms of a fiscal contraction is 1.1 in Belgium and 1.4 in France. A coordinated fiscal contraction in France and Italy is also shown to be detrimental to France in the long run, but it has almost no additional impact on the Italian GDP.

In terms of net effect, provided the fiscal contractions are used entirely to repay debt, the cost of this strategy for Belgium is doubled in comparison with outcomes in Table 2 in the short and long run; the cost increases by a third in France in the short and the long run. Italy is the exception as a coordinated strategy of debt reduction with France would increase its GDP by $0.2 \%$ and $0.4 \%$, respectively, in the short and the long run. This result may seem somewhat counterintuitive since both Belgium and Italy are plagued by high debt, and one would expect this to be more problematic for a small country than for a large one if the competitiveness of the former is more substantially hit than the competitiveness of the latter. Yet, a debt reduction has a non-Keynesian effect for Italy and not for Belgium because the Belgian track record regarding inflation has generally been better than the Italian's and has been disconnected from debt policy. 
Table 3. Impact of Common Fiscal Policy on Domestic GDP (with cross effects)

\begin{tabular}{|l|c|c|c|c|c|c|}
\hline & \multicolumn{2}{|c|}{ Belgium } & \multicolumn{2}{c|}{ France } & \multicolumn{2}{c|}{ Italy } \\
\hline & $\begin{array}{c}\text { Short } \\
\text { run }\end{array}$ & $\begin{array}{c}\text { Long } \\
\text { run }\end{array}$ & $\begin{array}{c}\text { Short } \\
\text { run }\end{array}$ & $\begin{array}{c}\text { Long } \\
\text { run }\end{array}$ & $\begin{array}{c}\text { Short } \\
\text { run }\end{array}$ & $\begin{array}{c}\text { Long } \\
\text { run }\end{array}$ \\
\hline Impact on GDP (in \%)... & & & & & & \\
\hline $\begin{array}{l}\text {..of a permanent fiscal contraction of } \\
1 \% \text { of GDP in France and Belgium }\end{array}$ & -0.55 & -1.10 & -0.55 & -1.40 & & -0.13 \\
\hline $\begin{array}{l}\ldots . \text { of a permanent fiscal contraction of } \\
1 \% \text { of GDP in France and Italy }\end{array}$ & & & -0.29 & -1.00 & -0.06 & -15 \\
\hline $\begin{array}{l}\text {...of a permanent debt reduction of } \\
1 \% \text { of GDP in France and Belgium }\end{array}$ & +0.15 & +0.30 & +0.15 & +0.40 & & +0.45 \\
\hline $\begin{array}{l}\text {..of a permanent debt reduction of } \\
1 \% \text { of GDP in France and Italy }\end{array}$ & & & +0.16 & +0.55 & +0.22 & +0.32 \\
\hline Net effect* & -0.40 & -0.80 & -0.40 & -1.00 & +0.16 & + \\
\hline
\end{tabular}

(Source) OECD, authors' computations

(Note) *: For France, maximum net effect for the pairwise with Belgium.

\section{A Counterfactual Experiment of Different Fiscal Rules}

After assessing the single and cross effects of fiscal consolidation in this paper's three representative countries, which help check that the parsimonious VAR gives reasonable outcomes, a counterfactual experiment is conducted. Drawing on single VAR estimates, the output gap and inflation paths corresponding to artificial time series of debt and deficit are simulated. Artificial series incorporate the different EU fiscal rules mentioned in the previous section (for details, refer to Appendix B).

The artificial fiscal impulse series used in the counterfactual experiment are the simulated change in the cyclically adjusted deficit corresponding to the fiscal adjustment paths consistent with the different rules to be tested. Thus, for rules constraining nominal balances, such as the Maastricht rule, the nominal golden rule, and the diminishing debt rule, the corresponding change in cyclically adjusted terms is computed starting from the hypothesis that a change in the fiscal adjustment path in $t-1$ influences growth and the output gap in $t$ and that this change in the output gap has only an effect on the cyclical component of the budget balance and does not affect its structural component in the short term. The new nominal budget balance in $t$ is calculated, adding to the original, unchanged structural budget balance, the new cyclical component. The new cyclical component in $t$ is obtained by applying the government budget elasticity to cyclical variations in economic activity calculated by the OECD to the simulated output gap in $t-1$, consistent with the fiscal adjustment strategy implemented. Afterwards, the nominal 
budget balance, thus obtained, is constrained according to the rule and adjusted for the cycle.

The effects on the output gap and the inflation rate of these different fiscal trajectories were compared, each consistent with one of the four rules. It was assumed that each of the four rules was applied from 2010 onwards, taking as given the 2009 levels of national output gap and inflation. It was further assume that no other major shock intervened. In other words, an "everything else equal" scenario was analyzed.

In order to rank the different fiscal rules, a metric-a quadratic loss function-of the following form was used:

$$
\mathrm{L}=\frac{1}{2}(y-\bar{y})^{2}+\frac{1}{2} \Delta \pi^{2}
$$

where $(y-\bar{y})$ is the output gap, and $\pi \Delta$ the inflation rate in difference. The assumption here is that authorities wish to minimize deviations from potential output and variations of inflation. This loss function assumes that the weights put on each objective are equal.

Beginning from the status quo, a rule that deficit should not exceed the $3 \%$ limit set in the Maastricht treaty (Figure 1) is established. For the three countries, one can observe that the debt to GDP ratio stabilizes largely above $100 \%$ of GDP, with the structural deficit converging towards $3 \%$ of GDP after the output gap comes close to 0 . The output gap starts from large negative values in the three countries, respectively $-6.0,-3.8$, and $-5.5 \%$ in Belgium, France, and Italy, and is gradually reduced. It is even slightly positive after 5 and 6 years in Italy and France, respectively.

Figure 1. A Counterfactual Experiment of the Maastricht Rule
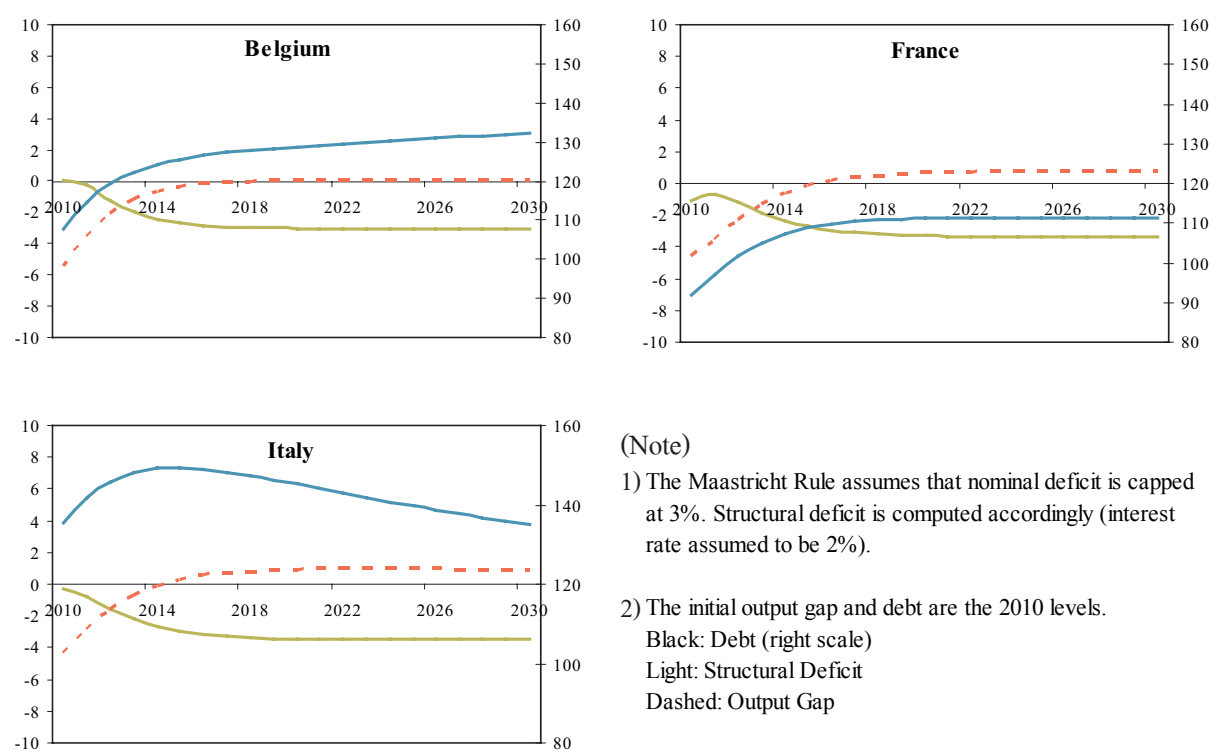

(Note)

1) The Maastricht Rule assumes that nominal deficit is capped at $3 \%$. Structural deficit is computed accordingly (interest rate assumed to be $2 \%$ ).

2) The initial output gap and debt are the 2010 levels. Black: Debt (right scale) Light: Structural Deficit Dashed: Output Gap 
The same experiment is carried out by imposing the new Fiscal Compact rule on the structural deficit (Fiscal Compact 1, Figure 2), i.e., capping the structural deficit at $0.5 \%$ of GDP. The most notable result is the impact of this new rule on public debt. The debt-to-GDP ratio would decrease by 35, 50, and 60 percentage points of GDP in Belgium, France, and Italy, respectively, 20 years after the adoption of the rule. It is noteworthy that the Fiscal Compact 1 would not have a different impact on the output gap than the status quo, except in Belgium where in this case, and like in France and Italy, the output gap would turn positive 6 years after implementing the balanced budget rule. The expansionary impact of debt reduction has already been mentioned as an outcome of the VAR estimations. It is even more apparent on the simulations based upon the Fiscal Compact 2-debt reduction rule (Figure 3).

Figure 2. A Counterfactual Experiment of Fiscal Compact 1-Structural Deficit Capped at 0.5\% of GDP
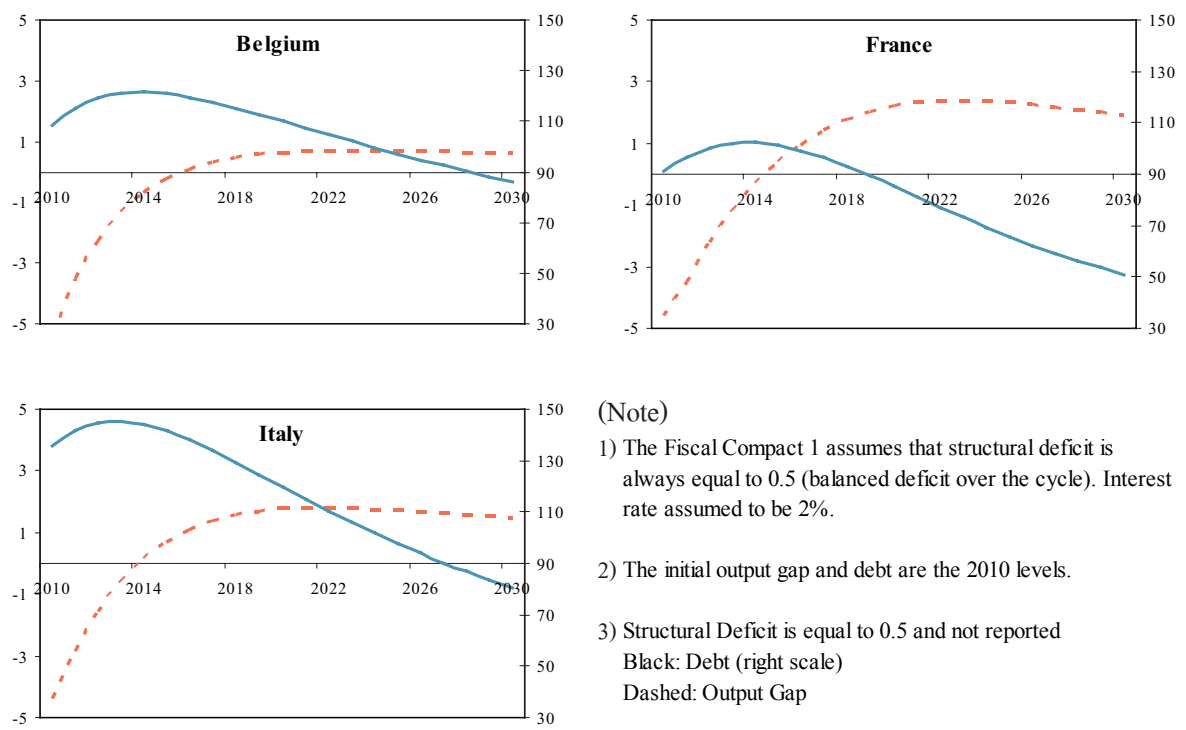

(Note)

1) The Fiscal Compact 1 assumes that structural deficit is always equal to 0.5 (balanced deficit over the cycle). Interest rate assumed to be $2 \%$.

2) The initial output gap and debt are the 2010 levels.

3) Structural Deficit is equal to 0.5 and not reported Black: Debt (right scale)

Dashed: Output Gap

The proposal to reduce each year the debt to GDP ratio by $5 \%$ of the difference with the $60 \%$ reference level is tested next and, in comparison with the Maastricht scenario or Fiscal Compact 1, it gives a radically different picture (Figure 3). The reduction of the debt level requires initially very large structural surpluses (almost $11 \%$ in the most indebted country, Italy) that are unrealistic because they are certainly socially unbearable and also because they have no historical precedent. It remains that despite these sharp fiscal consolidations, but because of the large and sustained decrease in public debt, output gaps would recover slightly faster than with other SGP rules (status quo and Fiscal Compact 1). As a consequence of fast recovery, the debt rule is always more inflationary than the other rules for the three countries under study.

Finally, a particular version of the golden rule is tested, i.e., assuming that the structural deficit is a balanced net of two components: a deficit of $1 \%$ per year to finance public invest- 
ment and debt depreciation caused by inflation (for all the experiments an interest rate of $2 \%$ is assumed). Results (Figure 4) show that such a rule would reduce the ratio of debt to GDP (albeit at a lower rate than the debt rule) while being less recessionary than the other rules in the short run and closer to the potential output in the longer run. It is worth noticing that simulations do not take into account the long run effects on productivity, hence on potential output, of an increase of the stock of public capital (for a survey of the literature, see Romp and De Haan, 2007). The present estimates may be considered as a lower bound and the real impact of the golden rule of public finance in this paper's framework is thus certainly underestimated.

Figure 3. A Counterfactual Experiment of Fiscal Compact 2-Debt Rule
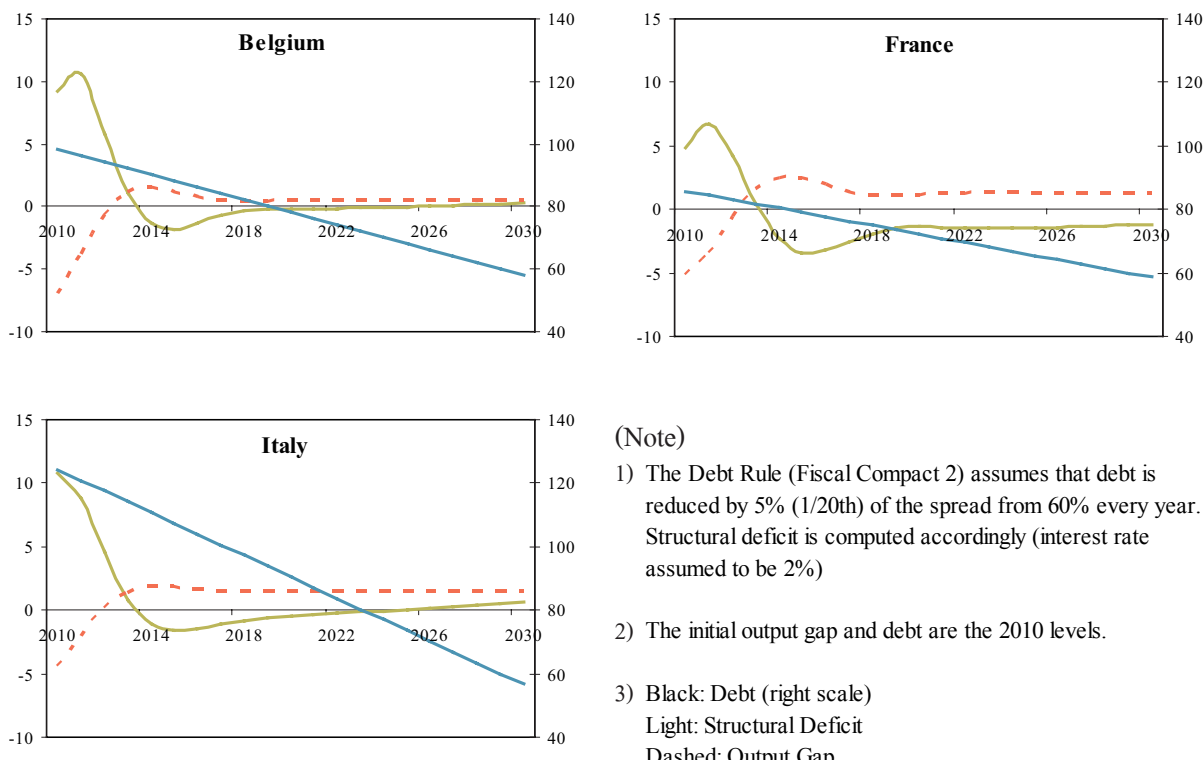

(Note)

1) The Debt Rule (Fiscal Compact 2) assumes that debt is reduced by $5 \%(1 / 20$ th) of the spread from $60 \%$ every year. Structural deficit is computed accordingly (interest rate assumed to be $2 \%$ )

2) The initial output gap and debt are the 2010 levels.

3) Black: Debt (right scale) Light: Structural Deficit Dashed: Output Gap 
Figure 4. A Counterfactual Experiment of the Golden Rule of Public Finance
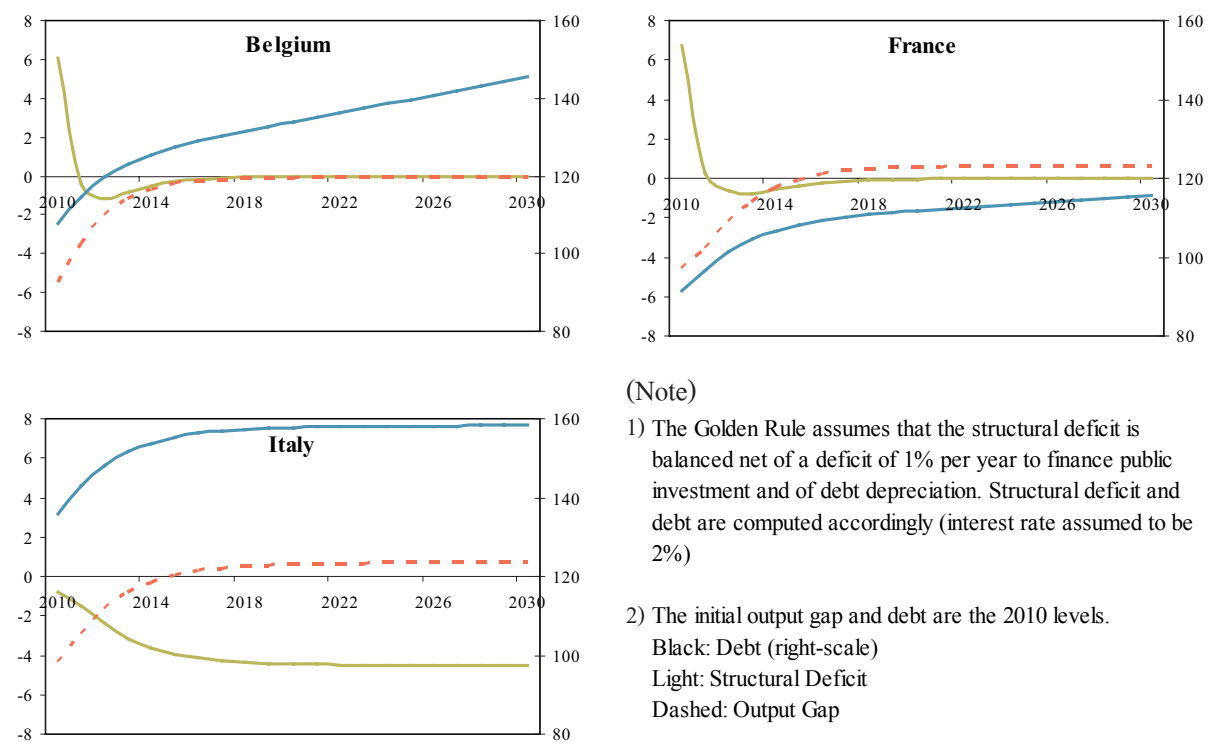

(Note)

1) The Golden Rule assumes that the structural deficit is balanced net of a deficit of $1 \%$ per year to finance public investment and of debt depreciation. Structural deficit and debt are computed accordingly (interest rate assumed to be $2 \%)$

2) The initial output gap and debt are the 2010 levels. Black: Debt (right-scale) Light: Structural Deficit Dashed: Output Gap

Drawing on this reduced-form VAR model, it appears that the Fiscal Compact, under its structural deficit cap or its debt-reduction scheme, leads to the highest output gap in the long run; it is more deflationary in the short run and more inflationary in the long run than the status quo and the golden rule of public finance. Debt reduction under the two provisions of the Fiscal Compact increases both inflation (in difference) and output gap according to the estimated coefficients of the VAR, whatever the country. It appears then that the property of the Fiscal Compact to stabilize the economy is weaker than the other two rules in the long run, according to the values of the loss functions reported in Table 4. They show that the golden rule of public finance is the most stabilizing fiscal rule for Belgium, France, and Italy, hence for three heterogeneous countries. The "second best" is the status quo with the Maastricht 3\%-of-GDP deficit cap. ${ }^{5}$

In the short run (Table 5), the rules' ranking is not straightforward. By short run, We mean one period after the fiscal rule has been implemented. The rule minimizing the loss function is the status quo for France and the golden rule for Belgium, whereas in the large and indebted Italy, the debt-reduction scheme of the Fiscal Compact gives the lowest loss value. In the case of Italy, due to its very high initial debt ratio, the debt reduction scheme produces a very sharp (though unrealistic) fiscal contraction at the time of the Fiscal Compact's adoption. One year after (in the short run), the fiscal impulse can thus be higher than under the provisions of the other rules: it is equal to $2 \%$ of GDP (a fiscal expansion), to be compared with 0.55 (status quo), 0.7 (golden rule), and 0.5 (Fiscal Compact 1). Hence, the recessionary impact of the debt-

\footnotetext{
5 A more conservative specification of the loss function, i.e., introducing a higher weight on inflation than on output, confirms the fiscal rules' ranking of the text.
} 
reduction scheme in Italy is the lowest in the short run.

Table 4. Value of the Loss Function in the Long Run

\begin{tabular}{ccccc}
\hline \hline 2030 & $\begin{array}{c}\text { Maastricht } \\
\text { Rule }\end{array}$ & SGP Rule & Debt Rule & Golden Rule \\
Belgium & 0.03 & 0.45 & 0.38 & $\mathbf{0 . 0 0}$ \\
France & 0.51 & 3.31 & 1.46 & $\mathbf{0 . 3 3}$ \\
Italy & 1.42 & 3.72 & 3.77 & $\mathbf{0 . 8 4}$ \\
\hline \hline
\end{tabular}

(Source) Authors' computations

Table 5. Value of the Loss Function in the Short Run

\begin{tabular}{ccccc}
\hline \hline 2010 & $\begin{array}{c}\text { Maastricht } \\
\text { Rule }\end{array}$ & SGP Rule & Debt Rule & Golden Rule \\
Belgium & 11.79 & 11.91 & 13.47 & $\mathbf{1 1 . 7 0}$ \\
France & $\mathbf{1 4 . 9 6}$ & 15.57 & 15.84 & 15.14 \\
Italy & 14.75 & 13.39 & $\mathbf{1 3 . 0 8}$ & 15.54 \\
\hline \hline
\end{tabular}

(Source) Authors' computations

The cumulative values of the loss functions for the three countries according to the adopted fiscal rule is also reported (Table 6). They give an assessment of the stabilization property of these rules from the short to the long run. Whatever the country, the lowest value is achieved when the golden rule of public finance is adopted, and the "second best" is the Maastricht fiscal rule. Quite interestingly, the two fiscal rules embedded in the Fiscal Compact are shown to perform substantially worse than the rule they complemented (the Maastricht rule). The performances of Fiscal Compact 1 and 2 are worsened respectively by $15 \%$ and $40 \%$ in Belgium, $114 \%$ and $68 \%$ in France, and $75 \%$ and $70 \%$ in Italy. The improvements in the stabilization property of the golden rule of public finance in comparison with the Maastricht rule are $0.6 \%$, $5 \%$, and $14 \%$ for Belgium, France, and Italy, respectively.

Table 6. Cumulative Value of the Loss Function, 2010 2030

\begin{tabular}{ccccc}
\hline \hline & $\begin{array}{c}\text { Maastricht } \\
\text { Rule }\end{array}$ & SGP Rule & Debt Rule & Golden Rule \\
Belgium & 42.88 & 49.50 & 58.49 & $\mathbf{4 2 . 6 0}$ \\
France & 42.69 & 90.58 & 71.39 & $\mathbf{4 0 . 5 7}$ \\
Italy & 57.08 & 100.65 & 98.83 & $\mathbf{5 0 . 0 8}$ \\
\hline \hline
\end{tabular}

(Source) Authors' computations

Finally, the robustness of fiscal rules' ranking to the initial output gap levels is checked. Creel et al. (2011) and De Long and Summers (2012) argue that fiscal contractions prove more 
recessionary as they take place when the output gap is already negative. The counterfactual exercise performed in this paper highlights this argument: the initial output gaps of the three countries are strongly negative and they hence pave the way for deeper recessions and deflations once strict fiscal rules are implemented. In order to escape a potential bias against those rules which are the most severe to implement like the Fiscal Compact, the counterfactual exercise setting at 0 or $2 \%$ the initial output gaps of Belgium, France, and Italy are reproduced to contrast with initial negative output gaps. ${ }^{6}$ In both cases, the ranking is confirmed in the long run regardless of the country, and the loss function is at its lowest if the golden rule is implemented. Results are a bit different when one turns to cumulative values of the loss function but only in the case of France. For this country, the lowest cumulative value is obtained with the status quo, and the golden rule is a "second best." If the initial output gap of France is set at 0 , the net gain of the status quo vis-à-vis the golden rule is $1.7 \%$; if it is set at $2 \%$, the net gain is $16 \%$.

Explaining the specific outcome for France is rather complex. Consider the transition from an initial situation with a negative output gap to an initial situation with a nil or positive output gap. The initial structural budget effort, which is required to cope with fiscal rules that are based upon the nominal budget balance (the status quo and the golden rule of public finance), is reduced because the cyclical deficit is capped at a lower level when the output gap is nil or positive. Hence, the restrictive feature of the status quo, which is based upon the sum of the cyclical and cyclically-adjusted deficits, is dampened by the introduction of a new assumption on the output gap. The cumulative values of the loss functions at the status quo are lower than with initial actual negative output gaps. This property holds for the three countries. It also holds, regardless of the country, when the golden rule is implemented, because this rule also draws partly on the nominal budget balance, but France differs from Belgium and Italy as its initial debt ratio is the lowest. The structural budget effort required to cope with the status quo is lower for France than for the other two countries because its interest charges are lower; but a relatively low debt ratio also means that the golden rule stimulus is relatively low in contrast with high-debt countries like Belgium and Italy. The golden rule stimulus depends partly on the depreciation of real debt caused by inflation. All else equal, the lower the debt, the lower the depreciation, and the lower the stimulus. In the case of France, the reduction of the cumulative values of the loss function at the golden rule is more than matched by the reduction of the cumulative values of the loss function at the status quo once the output gap has changed from negative to positive values because the initial low-debt ratio dampens the fiscal stimulus embedded in the golden rule of public finance.

\footnotetext{
${ }^{6}$ The initial inflation rate in difference was also set to 0 . Results are available upon request from the authors.
} 


\section{Conclusion}

At the outset of the financial and sovereign-debt crisis, European Union countries had to rethink the fiscal governance of the Eurozone. This paper discusses the different proposals which have been approved (or discussed) since 2010 and that involve the adoption of a "new Stability and Growth Pact" extended to the control of macroeconomic imbalances.

A common feature of EU fiscal reforms is that fiscal instruments are increasingly viewed as a final objective. Achieving fiscal balance and reduced public debts blurs the incidence of these policies on the output gap and inflation, hence on macro variables which are, with unemployment, the main and usual objectives of policy strategies.

In contrast with this view, attention is shifted on the macroeconomic consequences of European fiscal rules. Hence, an assessment is given of the impact of four fiscal rules on the output gap, inflation rates, and loss functions of three economies that are taken as representative of the Eurozone. The new rules which are analyzed are the debt reduction scenario by one-twentieth of the gap with the 60 percent limit per year and a cap on the cyclically adjusted deficit.

Drawing on these different fiscal rules, a hierarchy based upon their macroeconomic outcomes is characterized. The new debt rule would certainly lead to lower debt levels, hence to larger fiscal margins for maneuver in the future but, in steep contrast with the golden rule of public finance, it would be very costly to implement since the requirement to enforce a substantial consolidation in the short run would be considerably higher than that of a golden rule and would hurt the output gap and the inflation rate. The cap on the cyclically adjusted deficit also leads to unfavorable outcomes whereas the Maastricht status quo, with its cap on the overall public deficit, would be a kind of "second best" behind the golden rule of public finance which ranks first in this paper's assessment. These results largely confirm the analysis performed by the team behind this paper in a companion document (Creel et al., 2012) using a small scale New-Keynesian model. There, agents are partially forward-looking, and governments incur an interest rate penalty for excessive debt. The ranking of the rules and the underlying mechanism remains substantially the same.

A robustness check of this paper's counterfactual approach show that the main results of this study are not sensitive to a change of assumption regarding the initial output gap. The shift from actual negative values to nil or positive theoretical values do not change the fiscal rules' ranking in the long run. Consequently, the current EU fiscal framework is dominated by the golden rule of public finance.

Received 18 July 2011, Revised 20 July 2012, Accepted 26 July 2012 


\section{References}

van Ark, B. (2010), "Productivity, sources of growth and potential output in the Euro area and the US," Intereconomics, 1, 17-20.

Coenen, G., Erceg, C.J., Freedman, C., Furceri, D., Kumhof, M., Lalonde, R., Laxton, D., Lindé, J., Mourougane, A., Muir, D., Mursula, S., de Resende, C., Roberts, J., Roeger, W., Snudden, S., Trabandt, M., and in't Veld, J. (2012), "Effects of Fiscal Stimulus in Structural Models." American Economic Journal: Macroeconomics, 4(1), 22-68.

Creel, J., Heyer, E., and Plane, M. (2011), « Petit précis de politique budgétaire par tous les temps, les multiplicateurs budgétaires au cours du cycle », Revue de l'OFCE, 116, January, 61-88.

Creel, J., Hubert, P., and Saraceno, F. (2012), “An assessment of Stability and Growth Pact Reform Proposals in a Small-Scale Macro Framework,” OFCE Working Paper, n 2012-04.

Creel, J., Monperrus-Veroni, P., and Saraceno, F. (2009), "Fiscal policy is back in France and the UK," Journal of Post-Keynesian Economics, Summer, 31(4), 645-667.

Creel, J. and Saraceno, F. (2010), "The crisis, automatic stabilisation and the Stability Pact," Revista de Economía y Estadística, 48(1), 75-104.

De Grauwe, P. (2006), "What have we learnt about monetary integration since the Maastricht treaty?" Journal of Common Market Studies, 44(4), 711-730.

DeLong, B. and Summers, L. (2012), "Fiscal policy in a depressed economy," Brookings Papers on Economic Activity, Spring, p. 52.

DG EcFin (2009), European economy, Occasional paper 49, June.

DG EcFin (2011), European economic forecast, Autumn.

Eichengreen, B. and Wyplosz, C. (1998), “The Stability Pact: More Than a Minor Nuisance?” Economic Policy, 0(26), 65-104.

Hall, R. E. (2009), “By How Much Does GDP Rise If the Government Buys More Output?” Brookings Papers on Economic Activity, 2, 183-231.

Ilzetzki, E., Mendoza, E.G., and Vegh., C.A. (2010), “How big (small) are fiscal multipliers?” NBER working paper 16479 , October.

Knedlik, T. and von Schweinitz, G. (2011), "Macroeconomic imbalances as indicators for debt crises in Europe," IWH Discussion Paper, 12, August.

Leigh, D., Devries, P., Freedman, C., Guajardo, J., Laxton, D., and Pescatori, A. (2010), "Will it Hurt? Macroeconomic Effects of Fiscal Consolidation," Chapter 3 in World Economic Outlook, October 2010, IMF, Washington DC.

Monperrus-Veroni, P. and Saraceno, F. (2005), "Reform of the Stability and Growth Pact: Reducing or Increasing the Nuisance?" OFCE Working Paper, n 2005-01.

Mountford, A. and Uhlig, H. (2009), "What are the Effects of Fiscal Policy Shocks?" Journal of Applied Econometrics, 24, 960-992.

Nash, J. (1950), “The Bargaining Problem,” Econometrica, 18, 155-162. 
Nash, J. (1953), “Two-Person Cooperative Games,” Econometrica, 21, 128-140.

Romer, C.D. and Romer, D.H. (2010), "The Macroeconomic Effects of Tax Changes: Estimates Based on a New Measure of Fiscal Shocks," American Economic Review, 100(3), 763-801.

Romp, W. and De Haan, J. (2007), "Public capital and economic growth: a critical survey," Perspektiven der Wirtschaftspolitik, 8, s1, 6-52.

Rubinstein, A., Safra, Z., Thomson, W. (1992), "On the Interpretation of the Nash Bargaining Solution and Its Extension to Non-Expected Utility Preferences,” Econometrica, 60, 5, Sep., 1171-1186.

Wyplosz, C. (2006), "European Monetary Union: the dark sides of a major success,” Economic Policy, 21(46), 207-261. 


\section{Appendices}

\section{Appendix 1: A Counterfactual Experiment}

To give a quantitative assessment of different fiscal rules, a counterfactual experiment in the vein of the approach of Eichengreen and Wyplosz (1998) and Monperrus-Veroni and Saraceno (2005) was developed to inquire what consequences a reform of the SGP would have in terms of growth were it applied since 2010. The estimation results for individual countries are given below:

\section{Table A1. Belgium}

Sample (adjusted): 1972 2008

Included observations: 37 after Standard errors in ( )

\begin{tabular}{ccc}
\hline & BG_GAP & BG_DINF \\
\hline BG_GAP(-1) & 0.55 & 0.35 \\
\hline & $(0.13)$ & $(0.17)$ \\
\hline BG_DINF(-1) & -0.01 & 0.15 \\
\hline & $(0.14)$ & $(0.19)$ \\
\hline C & 0.07 & 0.14 \\
\hline & $(0.22)$ & $(0.28)$ \\
\hline BG_DCABS & -0.25 & -0.07 \\
\hline & $(0.12)$ & $(0.16)$ \\
\hline BG_DUMMY & -1.67 & 0.83 \\
\hline D(BG_GDEBT) & -0.10 & -0.06 \\
\hline & $(0.04)$ & $(0.05)$ \\
\hline R-squared & 0.60 & 0.25 \\
Adj. R-squared & 0.53 & 0.13 \\
Sum sq. resids & 44.73 & 75.67 \\
\hline
\end{tabular}


Table A2. France

Sample (adjusted): 1973 2008

Included observations: 36 after adjustments Standard errors in ( )

\begin{tabular}{ccc}
\hline & FR_GAP & FR_DINF \\
\hline FR_GAP(-1) & 0.65 & 0.78 \\
\hline & $(0.15)$ & $(0.22)$ \\
\hline FR_DINF(-1) & -0.12 & -0.15 \\
\hline & $(0.15)$ & $(0.22)$ \\
\hline C & 0.33 & -0.01 \\
\hline FR_DCABS & -0.28 & 0.27 \\
\hline & $(0.24)$ & $(0.36)$ \\
\hline FR_DUMMY & -1.34 & -1.11 \\
\hline & $(0.66)$ & $(0.97)$ \\
\hline D(FR_GDEBT) & -0.18 & -0.01 \\
\hline & $(0.06)$ & $(0.09)$ \\
\hline R-squared & 0.61 & 0.35 \\
Adj. R-squared & 0.55 & 0.24 \\
Sum sq. resids & 29.74 & 64.11 \\
\hline
\end{tabular}

Table A3. France

Sample (adjusted): 1973 2008

Included observations: 36 after adjustments Standard errors in ( )

\begin{tabular}{ccc}
\hline & IT_GAP & IT_DINF \\
\hline IT_GAP(-1) & 0.648 & 0.814 \\
\hline & $(0.14)$ & $(0.32)$ \\
\hline IT_DINF(-1) & -0.08 & -0.14 \\
\hline & $(0.10)$ & $(0.22)$ \\
\hline C & 0.33 & 0.46 \\
\hline IT_DCABS & $(0.20)$ & $(0.45)$ \\
\hline & -0.12 & 0.37 \\
\hline IT_DUMMY & $(0.14)$ & $(0.32)$ \\
\hline & -2.73 & -1.54 \\
\hline D(IT_GDEBT) & $(0.59)$ & $(1.33)$ \\
\hline & -0.11 & -0.14 \\
\hline R-squared & $(0.04)$ & $(0.08)$ \\
Adj. R-squared & 0.65 & 0.30 \\
Sum sq. resids & 35.37 & 0.18 \\
\hline
\end{tabular}

Results have already been discussed in the main text although it remains to be added that the coefficients of the VARs are satisfactory. Most noteworthy for this paper's purpose is that 
the change in the cyclically adjusted deficit and the change in public debt are statistically significant in the equation of the output gap in the Belgian VAR. The latter variable (the change in public debt) is also significant in the equation of the output gap in the French and Italian VARs. The change in the cyclically adjusted deficit is never statistically significant in the equation of inflation (in difference) whatever the country.

Extensions of the VAR to include cross-country effects give the following results:

Table A4. Cross Country Effects: France \& Belgium

Sample (adjusted): 1973 2008 - Included observations: 36 after adjustments Standard errors in ( )

\begin{tabular}{|c|c|c|c|c|}
\hline & FR_GAP & FR_DINF & IT_GAP & IT_DINF \\
\hline \multirow[t]{2}{*}{ FR_GAP(-1) } & 0.62 & 0.36 & 0.07 & 0.33 \\
\hline & $(0.20)$ & $(0.31)$ & $(0.24)$ & $(0.55)$ \\
\hline \multirow[t]{2}{*}{ FR_DINF(-1) } & 0.10 & -0.39 & 0.17 & -0.13 \\
\hline & $(0.17)$ & (0.26) & $(0.20)$ & $(0.46)$ \\
\hline \multirow[t]{2}{*}{ IT_GAP(-1) } & 0.07 & 0.48 & 0.52 & 0.80 \\
\hline & $(0.20)$ & (0.30) & $(0.23)$ & $(0.53)$ \\
\hline \multirow[t]{2}{*}{ IT_DINF(-1) } & -0.14 & 0.21 & -0.16 & -0.05 \\
\hline & $(0.10)$ & $(0.16)$ & (0.12) & $(0.28)$ \\
\hline \multirow[t]{2}{*}{$\mathrm{C}$} & 0.45 & 0.23 & 0.41 & 0.60 \\
\hline & $(0.19)$ & $(0.29)$ & $(0.23)$ & $(0.52)$ \\
\hline \multirow[t]{2}{*}{ FR_DCABS } & -0.31 & 0.47 & -0.00 & 0.75 \\
\hline & $(0.24)$ & $(0.36)$ & $(0.28)$ & $(0.64)$ \\
\hline \multirow[t]{2}{*}{ IT_DCABS } & 0.02 & -0.05 & -0.06 & 0.29 \\
\hline & $(0.13)$ & $(0.20)$ & $(0.15)$ & $(0.35)$ \\
\hline \multirow[t]{2}{*}{ D(FR_GDEBT) } & -0.11 & 0.08 & -0.15 & -0.10 \\
\hline & (0.07) & $(0.10)$ & (0.08) & $(0.18)$ \\
\hline \multirow[t]{2}{*}{ D(IT_GDEBT) } & -0.05 & -0.03 & -0.07 & -0.04 \\
\hline & $(0.04)$ & $(0.06046)$ & $(0.04710)$ & $(0.10748)$ \\
\hline \multirow[t]{2}{*}{ FR_DUMMY } & -0.573675 & -1.05 & -0.48 & -2.16 \\
\hline & $(0.66)$ & (1.01) & $(0.79)$ & $(1.80)$ \\
\hline \multirow[t]{2}{*}{ IT_DUMMY } & -1.66 & -0.99 & -2.30 & -0.32 \\
\hline & $(0.61)$ & $(0.93)$ & $(0.72)$ & $(1.64)$ \\
\hline R-squared & 0.73 & 0.51 & 0.71 & 0.40 \\
\hline Adj. R-squared & 0.62 & 0.31 & 0.59 & 0.16 \\
\hline Sum sq. resids & 20.98 & 48.53 & 29.45 & 153.33 \\
\hline
\end{tabular}


Table A5. Cross Country Effects: France \& Italy

Sample (adjusted): 1973 2008 - Included observations: 36 after adjustments Standard errors in ( )

\begin{tabular}{|c|c|c|c|c|}
\hline & FR_GAP & FR_DINF & BG_GAP & BG_DINF \\
\hline \multirow[t]{2}{*}{ FR_GAP(-1) } & 0.61 & 0.66 & 0.21 & 0.47 \\
\hline & $(0.22)$ & $(0.34)$ & $(0.28)$ & (0.39) \\
\hline \multirow[t]{2}{*}{ FR_DINF(-1) } & -0.25 & -0.02 & -0.47 & -0.01 \\
\hline & $(0.23)$ & $(0.37)$ & $(0.30)$ & $(0.41)$ \\
\hline \multirow[t]{2}{*}{ BG_GAP(-1) } & 0.16 & 0.21 & 0.51 & 0.15 \\
\hline & (0.18) & $(0.28)$ & $(0.23)$ & $(0.32)$ \\
\hline \multirow[t]{2}{*}{ BG_DINF(-1) } & -0.06 & -0.30 & 0.33 & 0.19 \\
\hline & $(0.18)$ & $(0.28)$ & $(0.23)$ & $(0.32)$ \\
\hline \multirow[t]{2}{*}{ C } & 0.44 & 0.11 & 0.12 & 0.06 \\
\hline & (0.20) & $(0.32)$ & (0.25) & (0.36) \\
\hline \multirow[t]{2}{*}{ FR_DCABS } & -0.37 & 0.23 & -0.24 & 0.22 \\
\hline & $(0.23)$ & $(0.37)$ & $(0.30)$ & $(0.41)$ \\
\hline \multirow[t]{2}{*}{ BG_DCABS } & -0.19 & -0.02 & -0.31 & -0.05 \\
\hline & (0.11) & $(0.17)$ & $(0.14)$ & $(0.20)$ \\
\hline \multirow[t]{2}{*}{ D(FR_GDEBT) } & -0.08 & 0.02 & -0.05 & 0.08 \\
\hline & $(0.07)$ & $(0.11)$ & $(0.09)$ & $(0.12)$ \\
\hline \multirow[t]{2}{*}{ D(BG_GDEBT) } & -0.08 & -0.10 & -0.10 & -0.06 \\
\hline & $(0.03)$ & $(0.06)$ & $(0.04)$ & (0.06) \\
\hline \multirow[t]{2}{*}{ FR_DUMMY } & -1.04 & -0.85 & -0.85 & -0.99 \\
\hline & $(0.65)$ & (1.04) & $(0.84)$ & (1.17) \\
\hline \multirow[t]{2}{*}{ BG_DUMMY } & -0.84 & -0.04 & -1.53 & 0.55 \\
\hline & (0.56) & $(0.90)$ & $(0.72)$ & (1.01) \\
\hline R-squared & 0.74 & 0.48 & 0.69 & 0.35 \\
\hline Adj. R-squared & 0.63 & 0.27 & 0.57 & 0.09 \\
\hline Sum sq. resids & 20.16 & 51.65 & 33.19 & 64.85 \\
\hline
\end{tabular}

Results show that the cross-effects of public finance data are statistically significant

- for Belgian public debt vis-à-vis French output gap

- for French public debt vis-à-vis the Italian output gap

Moreover, introducing these cross-effects of public finance

- reinforces the impact and statistical significance of the change in the cyclically adjusted French deficit on the French output gap

- reinforces the impact and statistical significance of the change in the cyclically adjusted Belgian deficit on the Belgian output gap

- reduces the impact and statistical significance of the change in French public debt on the French output gap

- reduces the impact and statistical significance of the change in Italian public debt on the Italian output gap 


\section{Appendix 2: Fiscal Rules}

After drawing on the (domestic and international) estimations presented in Appendix A, fiscal adjustment strategies that would result from the enforcement of each of the fiscal rules have been simulated. The following rules are tested:

- the Maastricht 3\% ceiling to nominal budget balance ( $s \geq-0.03$ where $s$ is the nominal budget balance/GDP ratio)

- the "nominal" golden rule $s+\left(I-\delta k_{0}\right)+D D \geq-0.03$, where I is the gross public investment/GDP ratio, $\mathrm{k}$ [subscript] 0 is the public capital stock/GDP ratio at the end of the previous period that is assumed to depreciate at a rate $\delta$, and DD is debt depreciation (after inflation)

- a diminishing rate of public debt towards the reference value of $60 \%$ of GDP by onetwentieth per year. The following system is simulated:

$$
\begin{aligned}
& b_{t}-0.6=0.95 *\left(b_{t-1}-0.6\right) \\
& b_{t}=b_{t-1}(1-g)-s_{t}
\end{aligned}
$$

where $b$ is the ratio of public debt to GDP, and $g$ is the GDP growth rate. The system can be rewritten in $\mathrm{s}$, hence

$$
s_{t}=b_{t-1}(0.05-g)-0.03 \text {. }
$$

Data come from the OECD Economic Outlook, 88, November 2010 issue. The output gap computed by the OECD according to the production function approach is used. Inflation is obtained as the change in the Consumer Price Index. The nominal budget balances are government net lending net of UMTS receipts, the cyclically adjusted deficit (surplus) consistent with an output gap calculated with the production function approach and coming from the same OECD source. 